\title{
ZNF479 Gene
}

National Cancer Institute

\section{Source}

National Cancer Institute. ZNF479 Gene. NCI Thesaurus. Code C143103.

This gene may play a role in the regulation of gene transcription. 